\title{
7 Opportunities and challenges for the British film industry
}

\author{
David Wilson
}

\section{General state of the British film industry}

According to data released by the British Film Institute (BFI), in 2018, along with the record high investment scale of film and television production, the British box office totaled $£ 1.282$ billion (the highest since the $1970 \mathrm{~s}$ ) (Figure 7.1), which indicates that Britain is still playing an important role in the world's film and television industry.

The 2018 film box office of UK was higher than the previous year, and one of the important contributory factors was the outstanding performance of domestic large-scale productions, such as Mamma Mia! Here We Go Again, Bohemian Rhapsody, Mary Poppins Returns, and Fantastic Beasts: The Crimes of Grindelwald (Table 7.1). In 2018, a series of blockbusters including Pokémon Detective Pikachu and Star Wars: The Rise of Skywalker started shooting, which are releasing or will be released worldwide in 2019-2020.

When talking about the British film industry in 2018, one important element should be considered is that the UK was going through Brexit. Obviously, Brexit will have a profound impact on British society. Economic factors such as national age ratio, social class structure, residents' income and education will change, British manufacturing and financial industries need to adjust accordingly.

The British film industry and the European Union have always been interdependent. Creative Europe plays a significant role in the European film marketing. A total of 39 countries (including 28 EU countries and 11 non-EU countries) are currently in the Creative Europe organization. Therefore, even after Brexit, Britain still needs to continue to have a cooperative relationship with Europe in the field of cultural creativity.

Many people believe that Brexit and the devaluation of the British pound promoted the growth of British film industry. The lower cost and tax reduction and exemption policies have attracted more American films to be produced in the UK. According to the British Broadcasting Corporation (BBC), from 2017, production costs from production agencies outside the UK reached $£ 1.7$ billion. 


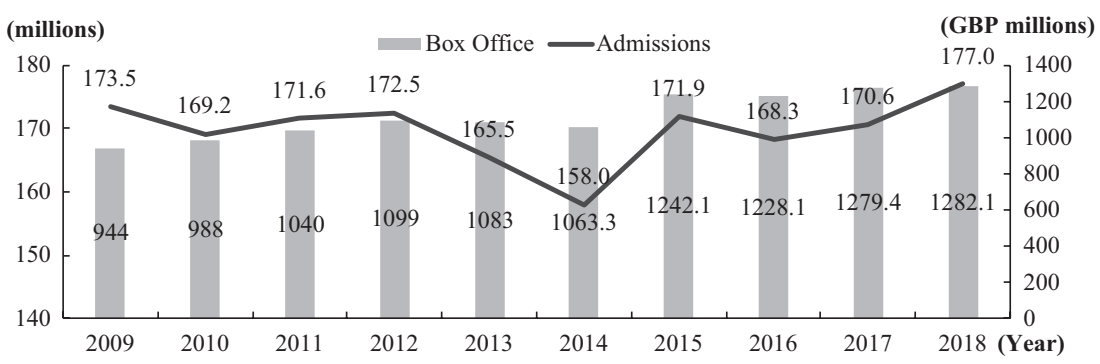

Figure 7.1 UK moviegoers and box office, 2009-2018.

Table 7.1 The top 20 films released in the UK and Ireland in 2018 ( $£$ millions)

\begin{tabular}{|c|c|c|c|c|}
\hline No. & Title & Countries & $\begin{array}{l}\text { Box } \\
\text { office }\end{array}$ & $\begin{array}{l}\text { Production } \\
\text { company }\end{array}$ \\
\hline 1 & Avengers: Infinity War & UK/USA & 70.8 & Walt Disney \\
\hline 2 & $\begin{array}{l}\text { Mamma Mia! Here We } \\
\text { Go Again }\end{array}$ & UK/USA & 65.5 & Universal \\
\hline 3 & The Incredibles 2 & USA & 56.2 & Walt Disney \\
\hline 4 & Bohemian Rhapsody & UK/USA & 52.0 & $\begin{array}{l}\text { 20th Century } \\
\text { Fox }\end{array}$ \\
\hline 5 & Black Panther & USA & 50.6 & Walt Disney \\
\hline 6 & Mary Poppins 2 & UK/USA & 42.1 & Walt Disney \\
\hline 7 & $\begin{array}{l}\text { Jurassic World: Fallen } \\
\quad \text { Kingdom }\end{array}$ & UK/USA & 41.6 & Universal \\
\hline 8 & Peter Rabbit & UK/USA/Australia & 41.1 & Sony Picture \\
\hline 9 & $\begin{array}{l}\text { Fantastic Beasts: The } \\
\text { Crimes of Grindelwald }\end{array}$ & UK/USA & 34.0 & Warner Bros. \\
\hline 10 & Deadpool 2 & USA & 32.7 & $\begin{array}{l}\text { 20th Century } \\
\text { Fox }\end{array}$ \\
\hline 11 & A Star is Born & USA & 29.9 & Warner Bros. \\
\hline 12 & The Grinch & USA & 27.8 & Universal \\
\hline 13 & Mission: Impossible - Fallout & UK/USA & 24.4 & Paramount \\
\hline 14 & Darkest Hour & UK & 24.1 & Universal \\
\hline 15 & Aquaman & USA & 22.1 & Warner Bros. \\
\hline 16 & Venom & UK/USA & 20.2 & Sony Picture \\
\hline 17 & $\begin{array}{l}\text { Hotel Transylvania } \\
\text { 3: Summer Vacation }\end{array}$ & USA & 20.1 & Sony Picture \\
\hline 18 & Solo: A Star Wars Story & UK/USA & 19.4 & Walt Disney \\
\hline 19 & Coco & USA & 18.9 & Walt Disney \\
\hline 20 & Fifty Shades Freed & USA & 17.8 & Universal \\
\hline
\end{tabular}

Source: comScore, BFI.

Note: Box office figures come from the UK and the Republic of Ireland, the single "territory" used for film distribution. Box office gross as of January 27, 2019, for films still in theaters on January 27, 2019. 
Brexit also limits the free movement of people. Forbes claimed in 2018 that the healthy operation of the film industry relies heavily on the free movement of people and equipment in different workplaces. In the UK, about 40 percent of staff in post-production, visual effects and 3D animation are non-British.

The British film industry is bound to face new challenges in attracting outstanding foreign film talent. More filmmakers have been calling for more job opportunities for new creative industry employees, and trying to retain a sufficient number of high-level professional teams to meet the needs of international films shot in the UK.

Much of the money invested in British films comes from Continental European funds. This investment mode is closely related to the European film market. After Brexit, the impact is incalculable. Although Brexit will have a negative impact on the British film industry, the British film industry also faces new development opportunities. The UK and China, India, Brazil and other countries are jointly developing co-production programs.

The British Film Institute (BFI) has given British filmmakers advice to help them deal with the problems caused by Brexit. Ways of film financing are diverse, among which money from the National Lottery is a vital one. Filmmakers often face fierce competition to gain investment money from the National Lottery. The BFI has been in charge of Lottery financing since the British Film Commission closed in 2011. From 2011 to 2018, the BFI has issued $£ 22,260,040,86$ in film funding, of which 45 percent was invested in film production. The distribution of BFI fund investments from April 2012 to April 2018 is shown in Table 7.2.

For film programs that meet their criteria, the BFI Fund gives varying degrees of subsidies to enable them to be effectively completed, and subsidies would be given to but not limited to the following categories: author copyright, priority adaptation rights, program $\mathrm{R} \& \mathrm{D}$ costs, producers' daily expenses,

Table 7.2 Investment distribution of BFI funds between April 2012 and April 2018

\begin{tabular}{|c|c|c|c|c|c|}
\hline No. & Type & Amount $(£)$ & No. & Type & Amount $(£)$ \\
\hline 1 & Manufacture & 99717783 & 9 & Documentary & 1882393 \\
\hline 2 & Education \& training & 36939567 & 10 & $\begin{array}{l}\text { Post-production } \\
\text { and film } \\
\text { completion }\end{array}$ & 1686789 \\
\hline 3 & Audience and events & 32409695 & 11 & $\begin{array}{l}\text { Publish } \\
\quad \text { (international) }\end{array}$ & 1373361 \\
\hline 4 & $\begin{array}{l}\text { Development and } \\
\text { pre-production }\end{array}$ & 18442878 & 12 & $\begin{array}{l}\text { Research and data } \\
\text { support }\end{array}$ & 822102 \\
\hline 5 & Publish (UK) & 16296657 & 13 & Other & 552000 \\
\hline 6 & Publicity for country & 6228910 & 14 & Diversity & 210925 \\
\hline 7 & Funds & 3634100 & 15 & Archive file & 180000 \\
\hline 8 & Short film & 2226927 & & & \\
\hline
\end{tabular}

Source: Stephen Follows, see https:// stephenfollows.com. 
legal staff costs, script editing costs in financing stage, pre-casting costs, and holding development rights fees, etc. Meanwhile, the BFI funding strongly supports original authors, including new filmmakers, relevant creative ideas to promote cultural progress, film programs with innovative content, innovative forms, film programs from outside London and the South-east region.

In 2018, the BFI announced the establishment of a new fund, the BFI Youth Audience Special Fund, whose aim is to promote the development of unique, high-quality content products that reflect the growth experience of British youth under the age of 18 .

London has long been the most frequent shooting location in the UK, but from 2017 to 2018, Yorkshire became an emerging hotspot for film and television production. The natural scenery and historical and cultural relics of the UK have attracted Indian filmmakers to come to the UK. The number of crews from Bollywood grows rapidly. Bollywood crews bring more job opportunities to British film production staff than local film production does.

\section{The rise of the video-on-demand (VOD) platforms}

The development of high-speed broadband and Internet interactive television has significantly changed the way British viewers watch movies and TV shows, which has been reflected in the rapid development of video-on-demand platforms, such as Netflix and Amazon in recent years. Accordingly, the rise of VOD platforms has had an impact on the employment rate in British film industry. According to a report from the Information Dissemination Office of the UK government, user numbers of Netflix, Amazon, and Now TV platforms have significantly surpassed that of traditional limited pay TV. The high emphasis on original content is a key element in the rise of VOD platforms. In 2018, 38 percent of Netflix users said that "choose to watch original content" was the reason for them to be subscribers, compared to 30 percent in the survey in the first quarter of 2017 (Figure 7.2). The movie Roma, presented by Netflix, has won Academy Awards, which has sparked wide discussions among filmmakers about VOD platforms hitting traditional cinemas. The VOD platforms also provide screening opportunities for films that cannot be screened in traditional theaters.

Today, the budget for programs of VOD platforms is as high as. if not even higher than that of traditional feature films, which provides film industry personnel and production-related services (such as hotels, vehicles and equipment rental, etc.) with a full-year's business. The British film industry's demand for experienced crew members has grown for two consecutive years. With the boom in film and television production, existing British film shooting bases are not enough, and new studios and new shooting sites should be built as soon as possible.

Parents and educators are concerned that children and teens can easily browse and watch uncensored online programs, which could be harmful 


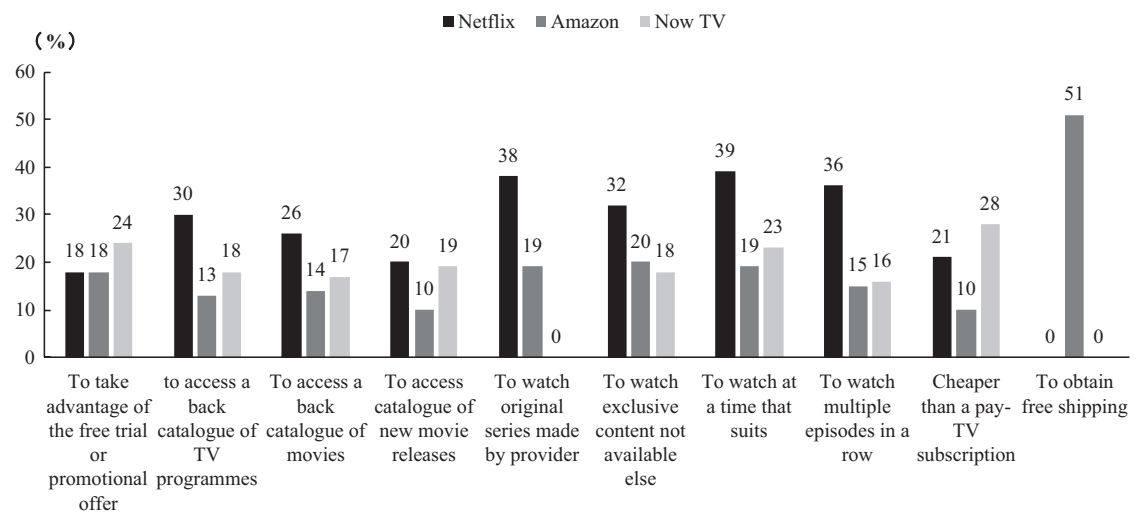

Figure 7.2 Reasons for choosing a video-on-demand platform.

to their mental and physical health. Netflix responded that it had obtained relevant permits, and its programs can be broadcast in the UK under the conditions of certain age. This was Netflix's response to social concerns, also the first time that the British film rating agency has granted a company the power to decide by themselves based on viewers' age under guidance. Netflix announced that they would use data calculations to decide whether to invest in a program, especially programs for non-adult audiences.

\section{Bilateral cooperation between Britain and China (Bradford and Qingdao)}

As early as 2014, China and the UK government signed an agreement to develop a mechanism to guide and encourage production agencies in both countries to cooperate in filmmaking. The UK has set up preferential tax policies and BFI fund assistance.

As the first "City of Film" recognized by UNESCO, Bradford has a rich and long history of film. Now, an increasing number of film and TV drama programs apply to the Bradford Film Office for filming licenses, including programs from the $\mathrm{BBC}$ and $\mathrm{ABC}$, as well as from Bollywood.

Bradford has been committed to developing partnerships with the Chinese film industry. Bradford, the City of Film, helped Qingdao in the process of applying for UNESCO City of Film status. A delegation from the China Film Association visited Bradford in April 2018. The Bradford delegation participated in the Golden Rooster and Hundred Flowers Film Festival in Foshan in 2018. Qingdao University of Science and Technology and the University of Bradford have begun cooperation in the field of animation education. 


\section{David Wilson}

The city of Bradford is developing into another UK film and television production and education center after London. At present, the British film industry is in a period of healthy development. If international cooperation with emerging overseas markets, such as China, can be strengthened in the future, the British film industry will surely start a long-term and successful path to prosperity and stability. 